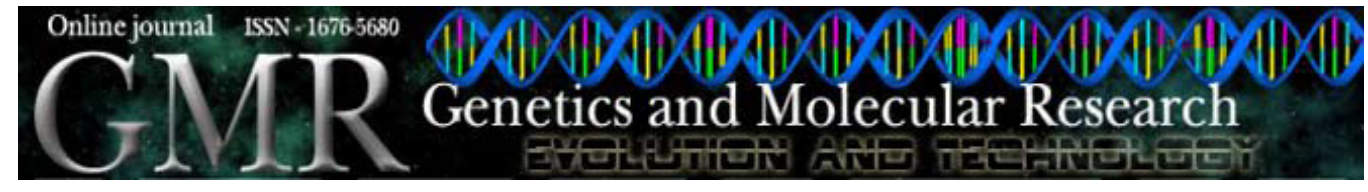

\title{
RAPD-based study of genetic variation and relationships among wild fig genotypes in Turkey
}

\author{
M. Akbulut ${ }^{1}$, S. Ercisli ${ }^{2}$ and H. Karlidag ${ }^{3}$ \\ ${ }^{1}$ Black Sea Agricultural Research Institute, Gelemen-Samsun, Turkey \\ ${ }^{2}$ Department of Horticulture, Faculty of Agriculture, \\ Ataturk University, Erzurum, Turkey \\ ${ }^{3}$ Department of Horticulture, Ispir Hamza Polat Vocational School, \\ Erzurum, Turkey \\ Corresponding author: S. Ercisli \\ E-mail: sercisli@hotmail.com
}

Genet. Mol. Res. 8 (3): 1109-1115 (2009)

Received May 11, 2009

Accepted June 5, 2009

Published September 15, 2009

\begin{abstract}
The fig tree (Ficus carica L.) is of significant socioeconomic importance in Turkey, with 25\% of the world's fig production. Genetic variation and relationships among 14 wild-grown figs sampled from Coruh Valley in Turkey were characterized by random amplified polymorphic DNA (RAPD). Ninety-eight DNA fragments were scored after amplification of DNA samples with 13 random primers; $70 \%$ of the scored bands were polymorphic. Genetic distances between the fig genotypes ranged from 0.21 to 0.62 . Genotypes 08 -ART- 02 and 08 ART-06 were found to be the most closely related, whereas 08-ART-09 and 08 -ART-10 were the most distant. The 14 wild-grown genotypes were grouped into six main clusters and one outgroup. We conclude that RAPD analysis is efficient for genotyping wild-grown fig genotypes.
\end{abstract}

Key words: Wild fig; Ficus; Random amplified polymorphic DNA; Genetic diversity 


\section{INTRODUCTION}

The East Mediterranean (Turkey, Syria, Saudi Arabia) where wild fig trees exist is considered to be the origin of the fig (Ficus carica L., $2 \mathrm{n}=16$ ) and the place from which its cultivation expanded to the whole Mediterranean. Currently, the fig grows best and produces the best quality fruit in the Mediterranean and dryer warm-temperate climates (El-Rayes, 1995).

Fig is one of the earliest cultivated fruit trees. Today, it is an important crop worldwide for dry and fresh consumption and its fruit is an important source of minerals and vitamins, and amino acids as well (Lianju et al., 2003). Dried figs also contain relatively high amounts of crude fiber $(5.8 \%, w / w)$, higher than that of all other common fruits (Vinson et al., 2005). Dried figs also contain one of the highest concentrations of polyphenols among the commonly consumed fruits and beverages (Vinson, 1999).

World fig production is dominated by mainly Mediterranean countries, and among them, Turkey is the world's largest fig producer with approximately 300,000 tons annual production ( $27 \%$ of the world's total production). The country is also the biggest fig exporter among the producer countries with 180,00 tons of exports annually, which represents $52 \%$ of the total world fig exports (Anonymous, 2005). About 70\% of Turkey's total fig production is for dry consumption (Aksoy et al., 2003).

Turkey bridges Europe, Asia and Africa, is surrounded on 3 sides with seas of different ecological characteristics, and has altitudes ranging from sea level to above $5000 \mathrm{~m}$, resulting in a variety of climatic conditions throughout the country. Thus, Turkey has a biological wealth that is unrivaled by any of the neighboring countries. The ecosystem mosaic of several different ecological characteristics provides nesting and breeding areas for thousands of fauna and flora species and their populations. Another factor that increases this wealth is that, two of the four migratory routes of the West Palaearctic Region pass above Turkey.

The country is one of the most important diversity centers of wild-grown figs as well. The wild fig trees grow mostly in Mediterranean, Southern and North East and North West Anatolia (Ozbek, 1978). In North West Anatolia, there is Coruh Valley where wild fig trees are abundant. In the valley, there is high morphological diversity among wild-grown fig trees, particularly in fruit color. Fruit color varies from dark purple to yellow. However, there is no information in the scientific literature regarding genomic information about wild fig trees grown in Coruh Valley.

Random amplified polymorphic DNA (RAPD) analysis is widely used for the study of such anonymous genomes. This method is suitable for determining genetic diversity, genotyping, phylogenetic analysis, genetic relationships, etc. RAPD, among other molecular marker methods, has considerable advantages because it is fast and inexpensive and because the development of RAPD markers does not require prior knowledge of the genome sequence. These markers have been widely used in the molecular analysis of figs (Elisiario et al., 1998; Galderisi et al., 1999; Cabrita et al., 2001; Papadopoulou et al., 2002; Aka-Kaçar et al., 2003; De Masi et al., 2003; Khadari et al., 1995, 2003; Sadder and Ateyyeh, 2006).

Therefore, the aim of this study was to use RAPD fingerprinting for characterizing and detecting polymorphisms among wild fig genotypes sampled from diverse environments of Coruh Valley in Turkey, and in addition, for investigating the genetic relationships among these genotypes sampled. 


\section{MATERIAL AND METHODS}

Leaf samples from 14 wild-grown fig genotypes were collected in Coruh Valley, which is located in Northeast Anatolia. The leaves were stored immediately at $-80^{\circ} \mathrm{C}$ for DNA extraction.

Genomic DNA was extracted from powdered (ground in liquid nitrogen) leaf materials using the modified method described by Lin et al. (2001). Approximately 10-15 mg tissue from each plant sample was snap-frozen in liquid nitrogen in 2-mL Eppendorf tubes. A volume of $1000 \mu \mathrm{L}$ DNA extraction buffer [100 mM Tris-HCl, pH 80; $50 \mathrm{mM}$ EDTA, pH $80 ; 500 \mathrm{mM} \mathrm{NaCl} ; 2 \% \mathrm{SDS}(\mathrm{w} / \mathrm{v}) ; 2 \%$ 2-mercaptoethanol $(\mathrm{v} / \mathrm{v}) ; 1 \% \mathrm{PVP}(\mathrm{w} / \mathrm{v})]$ was added and the tubes mixed well. The mixture was incubated at $65^{\circ} \mathrm{C}$ in a water bath for $40 \mathrm{~min}$ with intermittent shaking at 5-min intervals. The mixture was centrifuged at $12,000 \mathrm{~g}$ for $15 \mathrm{~min}$ at $4^{\circ} \mathrm{C}$. The supernatant was transferred to a clean $1.5-\mathrm{mL}$ tube, mixed with an equal volume of phenol:chloroform:isoamyl alcohol (25:24:1), and then centrifuged. The supernatant was collected and mixed with $1 / 10$ volume $10 \% \mathrm{CTAB}-0.7 \mathrm{M} \mathrm{NaCl}$ in a clean tube. After centrifugation, the supernatant was collected and mixed gently with an equal volume of chloroform:isoamyl alcohol (24:1). DNA was precipitated by the addition of 0.6 volume of freezer-cold isopropanol, for $10 \mathrm{~min}$ at $-20^{\circ} \mathrm{C}$. DNA was pelleted by centrifugation $(12,000 \mathrm{~g}$, $10 \mathrm{~min}$ ) and the isopropanol was poured off; the DNA recovered was allowed to air-dry before being dissolved in $100 \mu \mathrm{L}$ TE buffer.

The samples were screened for RAPD variation using the standard 10-base primers supplied by Operon. A $30-\mu \mathrm{L}$ reaction cocktail was prepared as follows: $10 \mathrm{X} 3.0 \mu \mathrm{L}$ buffer, $1.2 \mu \mathrm{L}$ dNTPs $(10 \mathrm{mM}), 1.2 \mu \mathrm{L}$ magnesium chloride $(25 \mathrm{mM}), 2.0 \mu \mathrm{L}$ primer $(5 \mu \mathrm{M}), 0.4 \mu \mathrm{L}$ Taq polymerase (5 units), $19.2 \mu \mathrm{L}$ water, and $3.0 \mu \mathrm{L}$ sample DNA (100 ng/ $\mu \mathrm{L}$ ). A total of 43 RAPD primers were tested in this study, and the polymorphisms obtained with the primers are shown in Table 1.

The thermocycler (Eppendorf Company) was programmed as follows: 2 min at $95^{\circ} \mathrm{C}$; 2 cycles of $30 \mathrm{~s}$ at $95^{\circ} \mathrm{C}, 1 \mathrm{~min}$ at $37^{\circ} \mathrm{C}, 2 \mathrm{~min}$ at $72^{\circ} \mathrm{C} ; 2$ cycles of $30 \mathrm{~s}$ at $95^{\circ} \mathrm{C}, 1 \mathrm{~min}$ at $35^{\circ} \mathrm{C}$, $2 \mathrm{~min}$ at $72^{\circ} \mathrm{C}$; 41 cycles of $30 \mathrm{~s}$ at $94^{\circ} \mathrm{C}, 1 \mathrm{~min}$ at $35^{\circ} \mathrm{C}, 2 \mathrm{~min}$ at $72^{\circ} \mathrm{C}$; followed by a final 5-min extension at $72^{\circ} \mathrm{C}$, and then cooling down to $4^{\circ} \mathrm{C}$.

PCR products $(27 \mu \mathrm{L})$ were mixed with $6 \mathrm{X}$ gel loading buffer $(3 \mu \mathrm{L})$ and loaded onto an agarose $(1.5 \%, \mathrm{w} / \mathrm{v})$ gel in $0.5 \mathrm{X}$ TBE (Tris-borate-EDTA) buffer, and electrophoresed at $70 \mathrm{~V}$ for $150 \mathrm{~min}$. The gel was stained in an ethidium bromide solution $(2 \mu \mathrm{L} / 100 \mathrm{~mL} 1 \mathrm{X}$ TBE buffer) for $40 \mathrm{~min}$, and the bands were visualized under UV in a Bio Doc Image Analysis System with Uvisoft analysis package (Cambridge, UK).

The positions of scorable RAPD bands were transformed into a binary character matrix ( 1 for the presence and 0 for the absence of a band at a particular position), which was entered in the RAPDistance computer program (Armstrong et al., 1994). These data were used for the calculation of pairwise genetic distances between cultivars using the Jaccard coefficient (JC). The computer program calculated the degree of genetic dissimilarity between each pair of the 21 genotypes using the simple equation: $\mathrm{JC}=1-a /(a+b+c)$, where " $a$ " is the number of bands shared by plant " $x$ " and plant " $y$ ", " $b$ " is the number of bands in plant " $x$ ", and " $c$ " is the number of bands in plant " $y$ ". The JC ignores the absence of matches. The distance matrix was used for cluster analysis using the unweighted pairgroup method with arithmetic averages. 


\section{RESULTS}

Initially, 43 decamer primers (Operon Technologies, Inc.) were tested in 14 wild fig genotypes. Of these, 13 primers (OPA 12, OPA 13, OPA 16, OPA 18, OPH 17, OPH 18, OPH 19 , OPX 11, OPY 04, OPY 07, OPY 11, OPY 15, and OPW 17) produced good amplification products and were chosen for RAPD analysis (Table 1). The remaining primers did not produce amplification products and scorable bands.

Table 1. List of the selected primers and the degree of polymorphism obtained among 14 wild-grown figs.

\begin{tabular}{llccc}
\hline Primer code & Sequence $5^{\prime} \rightarrow 3^{\prime}$ & Polymorphic bands & Monomorphic bands & $\begin{array}{c}\text { Percentage of } \\
\text { polymorphic markers }\end{array}$ \\
\hline OPA-12 & TCGGCGATAG & 3 & 3 & 50 \\
OPA-13 & CAGCACCCAC & 5 & 3 & 63 \\
OPA-16 & AGCCAGCGAA & 6 & 2 & 75 \\
OPA-18 & AGGTGACCGT & 5 & 1 & 83 \\
OPH-17 & CACTCTCCTC & 3 & 1 & 75 \\
OPH-18 & GAATCGGCCA & 7 & 3 & 70 \\
OPH-19 & CTGACCAGCC & 7 & 3 & 70 \\
OPX-11 & GGAGCCTCAG & 8 & 2 & 80 \\
OPY-04 & GGTCGCAATG & 3 & 2 & 40 \\
OPY-07 & AGAGCCGTCA & 8 & 4 & 75 \\
OPY-11 & AGACGATGGG & 5 & 3 & 63 \\
OPY-15 & AGTCGCCCTT & 5 & - & 100 \\
OPW-17 & GTCCTGGGTT & 4 & 2 & 67 \\
Polymorphism (average) & & 69 & 29 & 70 \\
Total & & & & \\
\hline
\end{tabular}

A total of 98 scored reliable markers were produced by 13 RAPD primers with an average frequency of 7.5 bands per primer. The size of the bands ranged from 240 to $2200 \mathrm{bp}$. Seventy percent of the total 98 bands produced were polymorphic. According to these results, there is a high level of genetic diversity in the wild fig germplasm in Coruh Valley.

The dendrogram obtained from the RAPD markers grouped the 14 wild-grown fig genotypes into 6 main clusters and one out-group. The first cluster includes 08-ART-01 and 08-ART-05. The fruit skin color of these genotypes is violet. The second cluster includes 08ART-08, 08-ART-12, and 08-ART-14, which have light violet and green skin color. The third cluster includes five genotypes (08-ART-02, 08-ART-03, 08-ART-06, 08-ART-10, and 08ART-11), which have mostly fruits with a yellow skin color, except 08 -ART-06 (green color). 08-ART-04, 08-ART-07, and 08-ART-13 formed single clusters (Figure 1), all of which have fruits with a dark violet skin color. The genotype 08-ART-09 has a violet color and was found to be the outgroup.

The genetic distance between fig genotypes ranged from 0.21 to 0.62 . The genotypes 08-ART-02 and 08-ART-06 were found to be the closest, whereas 08-ART-09 and 08-ART-10 were the most distant. 


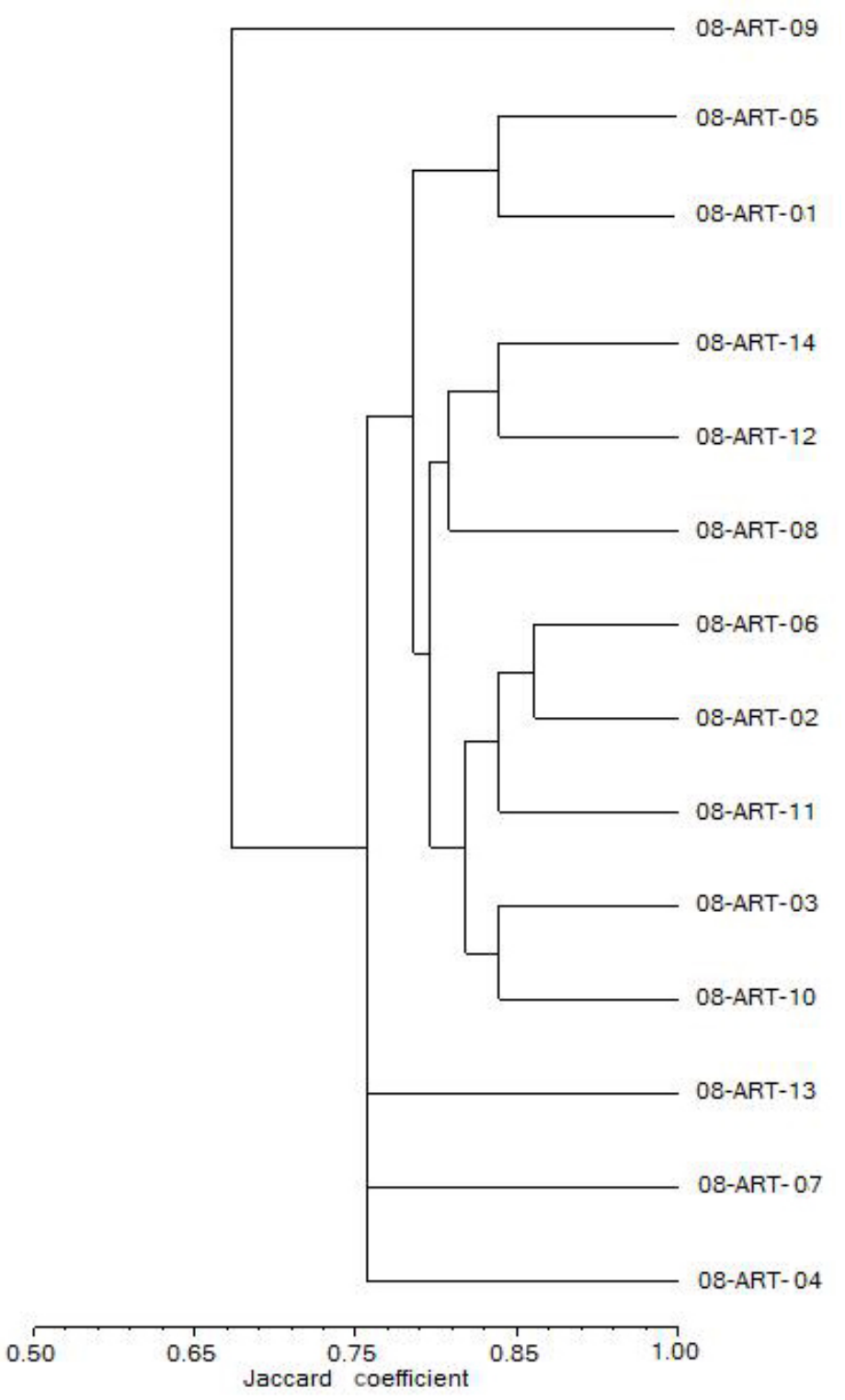

Figure 1. Unweighted pair-group method with arithmetic average dendrogram of 14 wild fig genotypes based on 13 random amplified polymorphic DNA primers.

\section{DISCUSSION}

Our study showed that there was very high polymorphism ratio among wild-grown fig genotypes (70\%) in Coruh Valley. Previously, the polymorphism ratio among cultivated figs 
grown in different Mediterranean countries was found to be $26-77 \%$, using RAPD markers (Kadari et al., 1995; Elisiario et al., 1998; Galderisi et al., 1999; Cabrita et al., 2001; Papadopoulou et al., 2002; Aka-Kaçar et al., 2003; De Masi et al., 2003; Salhi-Hannachi et al., 2005; Sadder and Ateyyeh, 2006). Our results are comparable to those in the cited literature. In fact, we used only wild-grown fig genotypes, which are exposed to diverse environments from different parts of Coruh Valley. Therefore, this high polymorphism ratio would be expected. On the other hand, an average similarity ratio of 0.468 was recorded for the wild-grown fig genotypes, suggesting that the genome may differ for the wild-grown Turkish figs. This result also indicates the potential use of these, particularly the more distant genotypes, for future breeding programs. Similar to the results obtained here, RAPD markers were shown in an earlier study to be powerful enough to differentiate even between clones of the same fig cultivars (Papadopoulou et al., 2002). The RAPD method has previously been found to be applicable for genotype identification in various gene pools, e.g., in Italy (Galderisi et al., 1999; De Masi et al., 2003), in Greece (Papadopoulou et al., 2002), in Turkey (Cabrita et al., 2001), and in Japan (Ikegami et al., 2009) as well. In addition, it is a very simple technique compared to other molecular techniques. Moreover, wild-grown fig genotypes present in Coruh Valley show variable fruit colors (e.g., yellow, green, purple, violet, and light and dark violet). Fruit weight is also variable among genotypes. Therefore, this rich and variable genetic pool could be potentially incorporated into local or regional breeding programs.

\section{REFERENCES}

Aka-Kaçar Y, Küden AB and Çetiner S (2003). Identification of varietal polymorphism in Ficus carica L. by RAPD (randomly amplified polymorphic DNA) markers. Acta Hortic. 598: 167-172.

Aksoy U, Balci B, Can HZ and Hepaksoy S (2003). Some significant results of the research-work in Turkey on fig. Acta Hortic. 605: 173-181.

Anonymous (2005). Food and Agriculture Organization of the United Nations. Available at [http://apps.fao.org/page/coll ections?subset=agriculture]. Accessed April 25, 2009.

Armstrong J, Gibbs A, Peakall R and Weiller G (1994). The RAPDistance Package. Australian National University, Canberra. Available at [http://life.anu.edu.au/molecular/software/rapd.htm]. Accessed May 20, 2009.

Cabrita LF, Aksoy U, Hepaksoy S and Leitao JM (2001). Suitability of isozyme, RAPD and AFLP markers to assess genetic differences and relatedness among fig (Ficus carica L.) clones. Sci. Horticult. 87: 261-273.

De Masi L, Cipollaro M, Di Bernardo G, Galderisi U, et al. (2003). Clonal selection and molecular characterization by RAPD analysis of the fig (Ficus carica L.) "Dottato" and "Bianco del Cilento" cultivars in Italy. Acta Hortic. 605: 65-68.

El-Rayes R (1995). The fig tree in the Mediterranean region and in Syria. Options Mediterr. 13: 79-83.

Elisiario PJ, Neto MC, Cabrita LF and Leitão JM (1998). Isoenzyme and RAPDs characterization of a collecion on fig (Ficus carica L.) traditional varieties. Acta Hortic. 480: 149-154.

Galderisi U, Cipollaro M, Di Bernardo G, De Masi L, et al. (1999). Identification of the edible fig 'Bianco del Cilento' by random amplified polymorphic DNA analysis. HortScience 34: 1263-1265.

Ikegami H, Nogata H, Hirashima K, Awamura M, et al. (2009). Analysis of genetic diversity among European and Asian fig varieties (Ficus carica L.) using ISSR, RAPD, and SSR markers. Genet. Res. Crop Evol. 56: 201-209.

Khadari B, Lashermes Ph and Kjellberg F (1995). RAPD fingerprints for identification and genetic characterization of fig (Ficus carica L.) genotypes. J. Genet. Breed. 49: 77-86.

Khadari B, Hochu I, Santoni S, Ater M, et al. (2003). Which molecular markers are best suited to identify fig cultivars: a comparison of RAPD, ISSR and microsatellite markers. Acta Hortic. 605: 69-89.

Lianju W, Weibin J, Kai M, Zhifeng L, et al. (2003). The production and research of fig (Ficus carica L.) in China. Acta Hortic. 605: 191-196.

Lin RC, Ding ZS, Li LB and Kuang TY (2001). A rapid and efficient DNA minipreparation suitable for screening transgenic plants. Plant Mol. Biol. Rep. 19: 379a-379e.

Ozbek S (1978). Ozel Meyvecilik. Vol. 128. Cukurova Universitesi, Ziraat Fakultesi Yayinlari, Adana. 
Papadopoulou K, Ehaliotis C, Tourna M, Kastanis P, et al. (2002). Genetic relatedness among dioecious Ficus carica L. cultivars by random amplified polymorphic DNA analysis, and evaluation of agronomic and morphological characters. Genetica 114: 183-194.

Sadder MT and Ateyyeh AF (2006). Molecular assessment of polymorphism among local Jordanian genotypes of the common fig (Ficus carica L.). Sci. Hortic. 107: 347-351.

Salhi-Hannachi A, Chatti K, Mars M, Marrakchi M, et al. (2005). Comparative analysis of genetic diversity in two Tunisian collections of fig cultivars based on random amplified polymorphic DNA and inter simple sequence repeats fingerprints. Genet. Res. Crop Evol. 52: 563-573.

Vinson JA (1999). The functional food properties of figs. Cereal Foods World 44: 82-87.

Vinson JA, Zubik L, Bose P, Samman N, et al. (2005). Dried fruits: excellent in vitro and in vivo antioxidants. J. Am. Coll. Nutr. 24: 44-50. 